\title{
Grameen Bank women borrowers' non-formal adult learning transformation in Bangladesh
}

\author{
Rouf, Kazi Abdur $\triangle$
}

Visiting Scholar, University of Toronto (rouf.kazi@utoronto.ca)

Associate Professor, Noble International University, USA

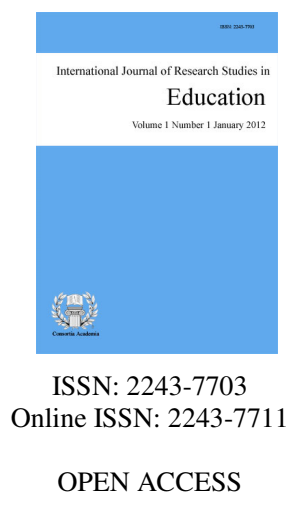

\section{Abstract}

Grameen Bank (GB) is a micro credit organization established to address poverty to empower the poor women in Bangladesh. GB targets adult women who were illiterate. GB's adult learning information has 'Sixteen Decisions' (inculcate the socio-economic messages) aimed at improving the social, economic, health, and well-being of GB borrowers. This Sixteen Decision adult learning campaign empowers GB women borrowers in their familial and communal life. It is important to know the efficacy of adult learning strategies that has used by GB to create this paradigm shift and transformation in local communities. How does the Grameen Bank adult learning process enables GB's women borrowers to mobilize group solidarity, leadership development and apply the sixteen decisions in their daily life? The study finds $87 \%$ GB women borrowers were able to make better family decision on behalf of the entire family. $25 \%$ of women vice-chairs won in local in Upzilla counsels in 2009 election in Bangladesh. This statistics indicate that gender changes are happening as women are becoming successful in representing their family and holding public offices in patriarchal Bangladesh. Exponential improvements in literacy is happening, (100\%) of GB borrowers are able to sign their names on the documents which show signs of achievements in adult learning. However, if GB non-formal adult learning strategies could streamline, this would generate more socio-economic consciousness and environmental awareness and social justice reforms to improve the life of GB women borrowers in Bangladesh.

Keywords: adult learning; Grameen bank; family space; leadership development, micro-credit; sixteen decisions 


\section{Grameen Bank women borrowers' non-formal adult learning transformation in Bangladesh}

\section{Introduction}

The Grameen Bank has run its group-based collateral free micro-credit and savings schemes, and campaigning sixteen discussions-through forming groups, centers, chairmen, center chiefs and issuing loans to its women borrowers (Ahmed \& Hakim, 2004). All these activities are done by oral face to face non-formal adult trainings and communications by GB twenty five thousand field staff to GB 1.9 million borrowers across Bangladesh. GB borrowers' adult learning is similar with Susan M. Brigham and Patricia A. Gouthro (2006) concept andragogy-learn in more individualized contexts (p. 84). Adult learning is about useful knowledge that helps create a more equitable world at individual, family, community and societal levels (Ahmed, 1999; 2002a; 2002b). It is about to build a more stable, safe and just society for the disadvantaged (Nesbit, 2006, p. 17). It also assists people development of their personality (Jung, 1954). GB credit transactions trainings, signatures learning and GB "Sixteen Decisions" campaigning among GB women borrowers through face-to-face group training, weekly center meetings, seven days workshops, exchange visits, annual gathering festivals and other action programs enhances socio-economic development to its borrowers in order to empower them in their family and in their community (Rouf, 2011). GB disseminates information that solicits women borrowers to become social actors and economic actors in Bangladesh. GB non-formal oral face-to- face adult trainings, communications and campaigns are effective for empowering marginalized people in Bangladesh

\subsection{Objectives}

$>\quad$ To study the operational practices of GB adult trainings and learning, communications and campaigns tools and processes for educating its borrowers on Grameen Bank "Sixteen Decisions" and its loan transactions in Bangladesh;

$>\quad$ To explore the role of GB adult learning practices in exposing socio-economic and environmental messages to GB borrowers;

$>$ To examine the implications of Grameen Bank adult learning in GB borrowers daily life, family decision making practices and civic engagement in their community?; and

$>\quad$ To explore and identify limitations of GB adult learning strategies and critical thinking ability among GB borrowers.

Through these questions, the study identifies factors that deter women borrowers' ability to participate fully in family spaces and public spaces within Bangladesh society.

\subsection{Statement of the Problem}

GB deals with illiterate, semi-literate adult clients. Hence it is important to know GB adult learning tools, procedures and strategies that has been practicing; what outcomes have happened at the grassroots levels because there has not been enough study on GB's adult learning and its influence to women's borrowers' private space and public space issues in Bangladesh. Therefore, author research focuses upon GB adult learning strengths and weaknesses for transforming GB non-formal training impact to empowering women's family space and public space development in patriarchal Bangladesh. 


\subsection{Research Questions}

The study seeks to address the following two research questions (1) Does the Grameen Bank trainings/communications/adult learning process able for GB's borrowers in transforming group solidarity, center leadership development and apply sixteen decisions in their daily life. (2) Are they are able to challenge and critical thinkers in Bangladesh? These questions are important in Bangladesh context because Grameen Bank's goals are not simply about financial credit, but it has a broader view of changing the role of women in Bangladesh. Its objective is not only to make marginalized women become economic actors, but also to empower women to participate as equals in the family decision making process and engage in public settings (Henry, 2006; Joan, et al., 2006; Yunus, 2008)

\section{Bangladesh Adult learning Context}

The Adult literacy rate (15 years and above) is 41.6 percent (Bangladesh Bureau of Statistics, 2001; Chowdhury et. al 2002; Government of Bangladesh, 1990). However, three years the literacy rate for the adult population 15 years and over is $38.8 \%$ (Education Watch 2005).

\section{Table 1}

Literacy rate by age and sex

\begin{tabular}{|c|c|c|c|c|}
\hline \multirow{2}{*}{ Age } & \multicolumn{3}{|c|}{ Sex } & \multirow{2}{*}{ Difference (Female-Male) } \\
\hline & Females & Males & Both & \\
\hline $11-14$ & 56.9 & 55.5 & 56.2 & 1.4 \\
\hline $15-19$ & 60.8 & 67.6 & 63.8 & -6.8 \\
\hline $20-24$ & 44.0 & 62.1 & 51.6 & -18.1 \\
\hline $25-29$ & 31.4 & 46.8 & 38.2 & -15.4 \\
\hline $30-34$ & 31.1 & 42.3 & 36.3 & -11.2 \\
\hline $35-39$ & 27.6 & 35.7 & 31.6 & -8.1 \\
\hline $40-44$ & 21.0 & 38.8 & 30.3 & -17.8 \\
\hline $45-49$ & 15.9 & $41-7$ & 28.4 & -25.8 \\
\hline $50-54$ & 10.3 & 40.9 & 17.9 & -30.6 \\
\hline $55-59$ & 7.3 & 33.0 & 20.7 & -25.7 \\
\hline $60-64$ & 6.7 & 39.4 & 23.4 & -32.7 \\
\hline $65-69$ & 2.5 & 32.0 & 19.4 & -29.5 \\
\hline $70-74$ & 4.6 & 21.2 & 14.2 & -16.6 \\
\hline 75 and above & 2.0 & 25.6 & 16.1 & -23.6 \\
\hline
\end{tabular}

Literate rate was highest for the age group 15-19 years, at 63.8 percent, with decreasing rates for the older age-groups. The low level literacy is a barrier to better productivity and earning. This situation suggests the need for an emphasis on the functionality of literacy skills and linking literacy activities with specific efforts to improve productivity and earning of people.

The non-governmental development organizations (NGOs) have been running literacy centres since 1960. The state also has spent substantial resources in literacy activities in the last two decades. The most prominent public sector literacy program is known as the Total Literacy Movement (TLM) carried out on a large scale in the second half of the last decade (Hussain, 2000; The Daily Star, 2002). However, non-literate by different levels of literacy skills in gender gap also exists in Bangladesh. Females lagged 12 percentage points behind their male counterparts (35.6 percent vs 47.6 percent (Education Watch 2005; UNIECF, 1992). In the rural areas non-literate rate is $53 \%$ females $56.5 \%$ and males $48.5 \%$. Urban non-literate females are $34.8 \%$ and male's 25.2\%. (NABBEIS, 2000) The below Table-2 data reflects different levels of non-literate in terms of reading, writing and numeracy varies. 
Rouf, K. A.

Table 2

Literacy rates in rural and urban areas in Bangladesh

\begin{tabular}{lcccc}
\hline \multirow{2}{*}{ Assessment areas } & \multicolumn{2}{c}{ Rural Bangladesh } & \multicolumn{2}{c}{ Urban Bangladesh } \\
\cline { 2 - 5 } & Females & Males & Females & Males \\
\hline Reading & 41.4 & 48.3 & 63.4 & 72.9 \\
Writing & 25.7 & 34.3 & 50.6 & 62.9 \\
Numeracy & 24.0 & 39.8 & 48.2 & 66.6 \\
Applications of all & 21.2 & 37.6 & 45.5 & 65.0 \\
\hline
\end{tabular}

Source: Education Watch 2002

The Education Watch (2005) findings on literacy do indicate a major national failure-failure in seriousness of effort, in setting priorities right, in applying professionalism to management and decision-making in education, and in lacking a vision and understandings of how literacy and non-formal education programs work (Nath, 2002). Moreover, the teaching learning process needed to be transformed in order to get better results (Haq \& Haq, 1998). The reason is the very poor quality of mainstream primary education is serious obstacles to better literacy outcomes, since one-third of those who complete primary education still remain illiterate (Education Watch, 2002).

\section{Methodology}

The paper used author`s own personal working experiences with GB and uses GB secondary data and reviews GB literatures. Author's past experience working with different MFI programs and the application of the Sixteen Decisions has influenced writing this paper. This paper enlarges readers about Grameen Bank adult learning strategies and knowledge.

\subsection{Background of the Study}

A key part of GB's strategy is bringing adult women together on weekly basis not only to pay their loans, but also to share experiences, support one another's business, inform sixteen decisions and their applications, and to hear from bank staff about how to keep their family healthy, keep the environment safe and prepare for natural disasters (Rouf, 2011). GB informs and provides these services through face-to-face dialogues between GB borrowers and GB staff. This adult learning process helps GB borrowers to be involved in familial activities, the family decision making process and community engagement, acquire literacy skills, and engage in family as well as community leadership skills so that they may represent themselves in the family and in the community and to be critical to their challenges. This non-formal adult education builds women borrowers' human capabilities and opens opportunities for them. It stimulates and empowers people to participate meaningfully in their own development. The GB Sixteen Decisions consciousness raising campaign and adult learning socio-economic leadership development process occurs through knowing and implementing the Sixteen Decisions; attending the group and center weekly meetings bridges the gap between the public and the private realms (Bouchard, 2006; Burton \& Point, 2006; Todd, 1996; Welton, 1995).

\section{Literature Review}

Adult literacy is a process of developing skills and knowledge and adult people applying these in their life rather than an event that ends with awarding a certificate (Selman \& Dampier, 1991). It is an effective literacy involves the integration of speaking, listening and critical thinking with reading and writing (Dawkins 1991; Fenwick, 2006). Adult literacy is part of the process by which illiterate people become aware of their personal situation and learn to do something about improving it. People who learn to read and to write can play a role in making their world a better place to live. It creates critical thinking among adult learners about their situation and develops consciousness about power, privileges and to challenge them. Moreover the critical adult education can lead to change in the way power is distributed in society (Parlo Freire, cited in UNESCO, 2000; 1997). 
According to Draper (1998), Illeris (2002), and Nesbit (2006) adult education context allows organizationally encompassing the three main and enduring traditions of adult education. (1) A set of unyielding social purpose, informed by passion and outrage and rooted in a concern for the less-privileged; (2) A systematic and sustained philosophical and critical analysis that develops the abilities to connect immediately individual experiences with underlying societal structures; and (3) A keen attention to the specific sites, locations, and practices where such purposes and analysis are made real in the lives of people (Freire, 1973, 1972, 1970; Nesbit, 2006). English \& Gillen (2000) and Leona English (2006) finds adult learning helps to know issues like power, identity, the subject and discourse and how these issues relate to and plays out in adult education. Sue Scott (2006) takes adult learning-the concept of transformation and explores its relevance to change at both personal and social levels.

Sawchuk (2006), Becker (1993), and Bouchard (2006) link human capital theory with adult education where he finds the application of human capital theory in adult education could result adult learners to economic and social responsibilities; learners could be able to relate between issues, and work and employment. Moses Coady (1939), pioneer of adult education, in his Book "Master of their own destiny" finds that adult learners enlightened and gained power and act to change their life situations through adult education. For example, the United Farmers of Alberta, Canada and the Saskatchewan Grain Growers Association (SGGA) build an educative democracy (Ibid, p. 25; Henson, 1946). Farmers learned democracy by actively participating in meetings where they learn to speak and act confidently. The farm local was a key educative form through lectures, study clubs, speakers, networks, farm newspapers, and the annual convocation. Through these social learning processes, individuals combined their intelligence (Tomkins, 1921). They used the dialogical methods in their just learning society. Hence adult education is the holistic learning society frame, whose purpose is to foster a more just and self-conscious learning process (Grace, 2006; Selman, 1998).

Wendy Burton and Gwen Point (2006) narrative about Indigenous education methodology is look, listen and learn. It is context specific and avoids imposing ones will on another. Storytelling is an essential feature of the lifelong learning of adult members of Aboriginal communities. Ceremonies play an essential role in imparting lessons and the further education of specialists (Poonwassie, 2001). Wendy Burton and Gwen Point (2006) mention that the grassroots activism of the 1960s resulted in community development such as leadership training, and consciousness raising which led to the development of Indian rights organizations-the National Indian Brotherhood.

Elizabeth A. Lange. (2006) believes that adult educators should be aware and critical as part of reflective thinking and reasoned inquiry. Through the process of adult learning, marginalized peoples can collectively uncover the power relations and hegemonic ideologies that disguise the true nature of social relations that prevent them from fulfilling their aspirations. GB sixteen decisions campaigns enlightened GB borrowers towards wellbeing life. This enlightened education attempts to resists the deepest levels of oppression and enhances ethical thinking of people (Foucault (1984).

Leona M. English (2006) studies Canadian Association for the Study of Adult Education (CASAE) from 1990 to 2004 and finds that adult education affects adults thinking, views of practice and perspective transformation. It embraces creative responses. Andre P. Grace. (2006) believes that critical adult education has predominantly concerned itself with advancing social and cultural forms of education focused on life, learning and work for adults. Moreover, Sue Scott (2006) believes that adult education includes engaging and analyzing adult change in progressive, positive ways. It helps adults to learn critical thinking and develop consciousness skills that can facilitate understanding of what is happening. Lifelong learning was advocated- particularly by UNESCO -as a model that would promote a better society and quality of life and allow people to adapt to and control change (OECD, 1996; UNDP, 1999; UNESCO, 2000; WCEFA, 1990). Hence it can be concluded in general, education and training are still based on raising an individual's competitiveness and human capital, and his/ her capacity for innovation and entrepreneurship. According to Kjell Rubenson and Judith Walker (2006) lifelong learning and new economy made connection between learning and earning. 
Adult learning also includes environmental non-formal education. Public environmental education (EAE) is about individual small change, expert knowledge, being with a deficit model-full of challenges (Clover, 2003; Darlene, 2006). Hence UNESCO environmental education includes awareness raising, information sharing, and individual behavior and attitude change. Here the key is to promote individual actions. GB $4^{\text {th }}$ slogan is campaigning for planting plants and grow vegetables throughout the year that GB borrowers do. GB borrowers are careful about environmental degradation.

\subsection{Adult Education Programs in Different Countries}

After Second World War, many newly independent nations launched mass literacy programmes/campaigns or eradication of illiteracy. One of the most widely publicized mass literacy campaigns was launched in Cuba in January 1961. Fidel Castro declared Cuba to be a:"Territory free from literacy" on December 1961 (Jennings, 2000). The Nicaraguan Literacy Crusade also receives world attention. A total of 80,000 literacy teachers were trained for the campaign (Deneer, 1981). After the Communist takeover of power in China in 1949, a campaign was started to achieve universal literacy. Thus the five countries including the Soviet Union reportedly made drastic reductions in the national illiteracy rate. The most well-known mass adult literacy programmes in the developing world was initiated by Dr. Frank Laubach; an American missionary working in the Philippines called: Each One Each One," Whereby volunteer tutors each taught an illiterate, who in turn would teach someone else.

The Experiential World Literacy Programme (EWLP), UNESCO launched in 1967 that included adult education, which earlier called fundamental education. EWLP basic idea was to combine literacy and numeracy with a program of education in basic vocational skills directly linked to the occupational needs of participants. This life-oriented literacy program not only concerns with economic, but also on health, nutrition, family planning, and other concerns related to daily living. The Total Literacy Campaign (TLC) in India was launched in 1988, has been undertaken in over 550 districts with a target of making 100 million people literate in a decades in the age group of 15-35 years. Freirean concretization influences can be seen in the Action Aid education projects (Action Aid, 2000) in Bangladesh and other South Asian and African countries named Regenerated Freirean Literacy through Empowering Community Techniques (REFLECT).

\section{Strategies}

\subsection{GB Micro-credit Program and Sixteen Decision Campaign}

Grameen Bank "Sixteen Decisions" is a socio-civic consciousness raising program and GB's group and center formation by-laws have leadership practices built-in. Grameen Bank group based micro credit operation meetings, campaigns, and trainings directly address their poverty issue (Rouf, 2011). Now in GB 97\% are women borrowers. Majority women borrowers (75\%) are below the poverty line (Yunus, 2011). However, women's economic growth cannot ensure women's free voice, choice and liberation from their male dominated families and communities. Hence GB designed Sixteen Decisions for borrowers for informing them for their wellbeing.

\subsection{GB Sixteen Decisions}

GB's field employees voluntarily discuss different issues and Sixteen Decisions, which are related to GB women borrowers social, economic, cultural, environmental and civic public space exploitation with clients in different venues, including the client's mini meetings, orientation meetings, open house meetings, weekly center meetings and especially in face-to-face informal group training sessions before clients receive their loans. GB has developed women's civic consciousness-raising program through following the Sixteen Decisions by its clients. Although all sixteen decisions are designed and stated in a simple way, few of them have direct tangible messages to create awareness among borrowers about socio-civic and economic issues. For example, among GB's sixteen decisions the $4^{\text {th }}, 5^{\text {th }}, 7^{\text {th }}, 8^{\text {th }}, 9^{\text {th }} 11^{\text {th }}, 12^{\text {th }}, 14^{\text {th }}$, 15th and $16^{\text {th }}$ decisions are directly related to women's 
private and public space development in the community. Some sixteen decisions principles have intangible social messages that contribute to creating positive spaces for women in their family and public space. For example, the $11^{\text {th }}$ slogan is to initiate dowry-free marriages among borrowers and their children, the $12^{\text {th }}$ slogan is that borrowers shall not inflict any injustice on anyone, neither shall they allow anyone to do so. Among GB's sixteen decisions, the $12^{\text {th }}, 14^{\text {th }}, 15^{\text {th }}$ and $16^{\text {th }}$ decisions are directly related to women civic rights consciousness-raising and promote a rights-based approach. Although all GB programs are targeted to women's socio-economic development, but its "Sixteen Decisions" campaigns, workshops, and trainings are aimed for their familial and community development. A study conducted by Kazi Rouf (2011) shows that $87 \%$ GB borrowers able to take decisions by all family members together. Although GB sixteen decisions don't have direct campaign for taking family decisions jointly; however, it is the transformation of GB adult learning outcomes that has resulted family violence reduces among GB families. However, still in some questions exist are all GB borrowers able to be self-critical, challenge status quo, and achieved their full potentials and self-empowerment in the community?

\subsection{Different Strategies for the GB Sixteen Decisions Campaign}

In 1984-1999, GB distributed the Sixteen Decisions' flyers to each center and asked borrowers to discuss them in groups in the weekly center meetings and other leisure time. GB field officials participated in the dowry-less marriages if borrowers invited them. Moreover, borrowers showed their center schools, vegetable plots, orchards, sanitary latrines and improved stoves to the GB field staff that they had grown and constructed. Borrowers also made separate savings for their children's education and children's wellbeing. This demonstrated that the different GB workshops, training programs, meetings, discussions and development programs have influenced the socio-economic life of the women borrowers of Grameen Bank.

\subsection{GB Borrowers Seven Days Workshop}

GB women once attended seven-day workshops and one-day workshops where women borrowers exchanged information, and follow-ups to the different workshops were conducted in 1979-1999. These workshops were conducted at the branches. Here, every participant had the chance to speak their life stories and build confidence, creating an atmosphere of warmth. These discussions were about the realities of women borrowers' lives such as discussions around their past suffering from poverty with children. The Grameen Bank women borrowers seven days workshops gave GB women borrowers new energy, brought out their own creativity, added new life skills knowledge and drove them to improve the male domination status quo (Bashin, 1991).

Usually one female borrower per center participated in the seven-day workshops and one-day workshops. In each workshop, thirty-five GB women borrowers from thirty-five centers would participate. Breakfast and launch were served in the workshop from the Bank. In addition, the bank distributed fruits/timber samplings, vegetable seeds, ORS packets, Alum packets and iodized salt packets to the participants. Two women program assistants facilitated each workshop. Different posters on women's liberation, women's health, children's health, balanced diets, vegetable production, homestead gardening, backyard poultry, community forestry, and adult literacy were displayed in the workshop room. In the workshop, GB also demonstrated how to prepare oral saline at their home for diarrhoea prevention, sanitary latrines, safe child delivery, cooking, soil improvement, stoves, solar energy, and biogas plants etc.

Moreover, in the workshops different subject specialists resource persons came from outside; like medical doctors from public hospitals, educationalists, nutritionists, nursery planners, agriculturalists, livestock officers, fisheries officers, cottage industry officers. They talked about primary health care, women's health, children's heath, child nutrition, child education, livestock vaccination, crop production, and integrated pest management (IPM) in the workshops and deliver lecturers. Moreover, GB high officials like zonal managers, area managers, program officers and branch managers of Grameen Bank also talked in the workshops. Workshop facilitators, GB officials discussed in detail the "themes and benefits of the Sixteen Decisions" to the participants. GB 
officials explained the effects of dowry, teenage marriage, the benefits of using sanitary latrines, women's unity etc. Workshop participants arranged dowry-less marriages in the workshop and GB praised those who arranged dowry less marriages and discouraged teenage marriage. GB field employees discussed those initiatives in the weekly center meetings too. It is important to note that workshops lectures avoid one way delivering lectures in workshops sessions, rather enhance interactive dialogues that are more effective to workshops' participants.

Kanud Illeris (2002) finds adult learning is the building blocks of human development in the areas of cognition, emotion, and social interaction. In these perspective, although the GB Sixteen Decisions campaigns do not exactly follow the strategies and themes of the western type of consciousness-raising discussions like women experiencing violence from their male partners, sexism, mothering, women housewification, discrimination of gender division of labour, women's subordination, women's abuse and domestic violence, personal is political; however, GB officials discussed the process of women's marginalization, women's exploitation, injustice and oppression process by the elites, money lenders and landlords. GB always gave advice to its borrowers to see their daughters and sons as equals, not to discriminate on children based on sex, rather to give them all an education. GB advises its clients to instead of spending money on a dowry for their daughter's wedding rather to spend money on her education so that she could become exposed and aware of her different rights, and issues in the family and in the community.

\subsection{GB Follow-up Workshops}

Grameen Bank also organized follow-ups to the seven-day workshops where participants share their ideas, skills and knowledge with their center members immediately after the workshops. Moreover, GB women clients conducted one-day picnic gatherings within their neighbourhoods after three months of the workshops where they cook together, eat together, play together, discuss together about their groups, center and identified problems and issues for solving collectively. In this gathering, GB employees also joined and discussed and reviewed the center performances.

\subsection{GB Exchange Visit Program}

Paulo Freire in his book Pedagogy of the Oppressed (1970) and Education for Critical Consciousness (1973) uses the term consciousness, understand what one reads and to write, creates and recreates an attitude-a self-transformation producing a stance of intervention in one's context (Freire, 1973, cited in Jennings 1990). The critical consciousness transformation applications can also see through exchange-visit programs of Gramen Bank where center chiefs stayed in other branch centers clients' houses for three days. Then hosted center chiefs stayed in guest center chiefs' houses of the other branch for three days. At the $7^{\text {th }}$ day both women borrowers' and branch managers sit together and reviewed borrowers' observations and experiences in the review session. Borrowers discussed what they observed and learnt from the exchange visits to other branch centers: women borrowers' loan utilizations and their businesses status, children's education, housing, whether the Sixteen Decisions were followed by the borrowers individually, and collectively in centers, balanced diet preparation, harmonious relationships with the family members, used sanitary latrines, drank pure drinking water, grew and ate vegetables, mentioned center discipline, integrity among center members etc. Through this exchange visit program, GB women borrowers identified each one's positive and negative features of the Sixteen Decisions, their loan performance portfolios and the respective centers' discipline. Women borrowers this physical movements to other centers in other branches, attending different center meetings as guests drove them to develop their psychological development and social mobility in their life by networking among neighbouring branches' women borrowers; it helped them to share, exchange and learn ideas from homogeneous likeminded women borrowers. However, now these excellent programs are closed in GB because of funding and GB field staff overloaded with loans transactions. 


\subsection{GB Borrowers Annual Gatherings}

Sue M. Scott. (2006) identifies individuals intend to learn from events and messages. This theory implication can be found in GB annual gatherings. GB women borrowers' gathered annually (Barsha Purti) and celebrated their business fairs in every branch every year until 1995. In this annual gathering, 1500-3000 borrowers gather together in their locality; chat and interactions each other and sell their products in these gatherings. Children jointly showed their parades, gymnastics, dance, songs and theatre in these occasions. Sometimes, Muhammed Yunus participated and celebrated these annual festivals fairs and children's games along with borrowers. These annual gatherings had an impact on borrowers' lives, and their family members. For example, they feel they are not alone or isolated, rather they assumed they are important people and are united in the community. Moreover, the rural elites saw these events and saw that these people had awakened and were participating in the social-economic life of the community. These annual gathering festivals have multiple impacts in borrowers' leadership development in their private and public life; however, now this program has closed because bank branches need a long time and a large budget to organize such events every year. The field employees find it is now difficult for them to manage time to organize such huge events in addition to their huge loan disbursement and loan collection jobs. A bank worker now deals with 600 borrowers' different types of loan proposals-flexible loans, education loans, and micro-enterprise loans, collect pension schemes money, selection of children for scholarships etc., loan disbursement, loan collection, savings collection, and group training.

\subsection{Grameen Bank Women Borrowers Leadership Skills Development}

Moreover, GB's group, center leadership practices built in Grameen Bank peer lending credit program has been trying to develop their leadership development and to empower them to develop their decision making abilities within their families as well as in the public space. Borrowers' understanding of GB's by-law and 16 slogans can help them remove barriers in empowering women against male domination in family spaces and public spaces in the villages. When these barriers are understood by women, it is easier for them to address the issues of women's empowerment and leadership development in private and public spaces. For example, GB borrowers stand against and protest against GB dismantled government policy in Bangladesh in 2013. Now Government of Bangladesh withheld GB dismantle policy.

Through center meetings discussions and interactions among them, GB borrowers become exposed to various issues and are informed about different developmental information, interact with their centre members resulting in the development of a harmonious relationship among centre members and develop social solidarity, integrity, and promote cohesion and women's awareness about their various human rights issues. GB borrowers' weekly meetings have implications to women intra-household power relations, "family partnerships," their cognitive development and adult learning dialogue engagement sensitized them about their deprivation. These adult learning dialogues develop their confidence, reinforce and nurture them to achieve gender equality; however, still patriarchy hurts them, confuses them, and makes them inferior, invisible, disempowered and oppressed women in the family and in the community context. Bangladeshi many scholars realize that patriarchal oppressions are unacceptable and uncomfortable for them (Abdullah, 1973; Jahan, 1995; Mahamud, 2004; Rathgeber, 1990) because husbands, fathers and brothers are controlling their wives, daughters and sisters respectively; women are not free from patriarchal dominance in their society. Although GB borrowers are not challenging patriarchal values and norms where they are living; however, GB sixteen decisions adult learning campaign has created aware them about this issue. As a result, the patriarchal values and norms are melting down as their logical arguments cautions to their mates and community elites.

\subsection{GB Adult Learning is working for GB Women Borrowers' Financial and Non-financial Development}

GB has initiated several projects for marginalized women's income generation and environmental projects for increasing their self-employment and paid-employment and to raise awareness about various issues that are related to marginalized women in the villages in Bangladesh. GB orients these programs to its borrowers through 
non-formal adult learning training, discussions and dialogues that mentions earlier in the paper. GB different literatures mention that GB is successful to implement is different schemes like micro-credit, savings mobilization, education loans, housing loans, latrine loans, handloom loans, crop production loans, agricultural projects for irrigation, seed production, seed preservation, distributing vegetable seeds, oral saline (ORS), alum distribution for pure drinking water, crop processing machines, community forestation, fortified yogurt plants for eradication of child malnutrition, eye hospitals, rural pathological clinics, paramedic clinics, livestock development, poultry development, rural children's education center, cell phones, nursing training, rural garments, mini bio-gas plants, home solar system, and improved stove distribution (Todd, 1996). All these tangible material development projects and intangible projects (civic development, leadership development, critical thinking and challenge status quo), ideas disseminate and organized and conducted by face to face workshops, trainings and meetings. GB provides information on public health, nutrition, adult education, women's rights, immunization, vaccination for livestock, integrated pest management (IPM), and homestead gardening for GB borrowers in the centers (Ibid, 1996).

Several NGOs and many international organizations are attempting to address the feminization of poverty, the dowry issue and to empower women in Bangladesh, but they are working piecemeal and often cancel out each other's efforts. Therefore, NGOs alliance with an inclusive women's collective action awareness empowerment project and campaign needs to be included, which should be an integrated development program that includes income-generation, education, health, agricultural and legal services for poor women at the village level. This is urgently needed because for poor women, their poverty is not just an issue of increasing income, and fulfilling basic needs, but fulfilling their fundamental human rights (Collins, 2006), abolishing dowry, teenage marriage, gender division of labour, sex discrimination, the devaluation of women's domestic chores, and the abuse of women in the family spheres and public spheres still are concern too.

\subsection{Revision of the 16 Decisions and revitalizing the 16 Decisions Adult Learning Awareness Campaign}

Currently, GB is not organizing Sixteen Decisions awareness campaign workshops to explain the significance of the Sixteen Decisions to women. Now, GB has begun printing the Sixteen Decisions on the backside of the borrowers' loan pass book and borrowers themselves can read these sixteen decisions and possibly reflect on how they might impact the socio-civic-environmental issues they face. The campaign through printed material supply strategy is not enough to raise awareness among the borrowers of the challenges and opportunities they face for socio-economic development for marginalised people (Bhola, 1984). However, GB women borrowers fell free and comfortable to visit GB offices, and to work with GB employees. For example, Majeda, a GB borrower says,

"My husband is alive. To do public functions, it requires interactions with males, but religious leaders' are against it and claim that women are breaking Purdah. Society may treat me badly unveiled and I might be unaccepted in my society. However, in GB, we women can retain our purdah because there is a separate restroom for women in grameen bank offices. Moreover GB officials respect us. I don't care village whispering."

GB Sixteen Decisions campaign and its implementation by GB women borrowers follows the Sustainable Development Approach too because GB women borrowers not only encompasses income-generation, and bring money in their family but the "Sixteen Decisions" campaign is also a process that incorporates people-centered development (Joan, 2006; Korten, 2003; Sen, 1996) where massive women have participated in this "Sixteen Decisions" campaign for their socio-economic and cultural development. Moreover, GB adult learning different principles and slogans are socially, environmentally and economically sound, follow sustainable business practices and promote stewardship of the local social economy.

GB borrowers are gradually moving to make their space in all local councils regional councils, and national councils; and participate in the public decision making processes. Elites people now counts them, sit them in 
elites meeting, or any other public occasions and events. Previously these disadvantaged people were used to work as labors in elite' lands, houses now they become their colleagues in the councils. For example, in 2008, there were 79 Grameen Bank women borrowers running for Upzilla vice-chairmen for the first time in Bangladesh. In each of the constituencies of the Upzilla vice-chairmen, there are 250-300 Grameen Bank centres. These GB borrower candidates visit the centres and campaign and borrowers also campaign for them. This networking process helped these 79 women vice-chairmen win the elections (25\% of the total seats) and they are now representing marginalized women. This statistics indicate that gender changes are happening as women are becoming successful in representing their family and holding public offices in patriarchal Bangladesh. Although many borrowers are not yet formal councillors, they are nevertheless invited by their respective formal elites or informal village elites to attend the hearing committee meetings. Now, if village elites make an unjust decision against marginalized women, the Grameen Bank borrowers who participate in the meeting protest against the injustice or suggest an alternative solution. For example, Sophina says:

If I am not present in my community hearing committee, the Union Parishad member (Councillors) shall wait until I arrive before making the decision.

\subsection{GB Women borrowers' opinion of their engagement in community activities}

In this regards a research report (Rouf, 2011) finds that two-thirds of participants' say that they like to participate in community activities. Borrowers' regular visit to Grameen Bank office, center schools, attending workshops enhances their public space development. For example, Halima, borrower of GB says:

"By joining in GB, my mind has opened, my intelligence, experience and ability to speak to different people has also increased. I distribute relief and senior's allowances to my neighbours. Moreover, I have developed my family decision-making skills."

GB borrowers have also determined for their second generation education. They do not want their daughters to suffer from illiteracy. Hence GB women borrowers encourage their daughters and sons to pursue higher education. For example, one GB borrower Shajeda says:

"I sent my first son to Cyprus and I shall send my second son abroad for studying higher education". This is implication of $5^{\text {th slogan }}$ of the sixteen decisions.

\section{Implication}

The end product of this paper encourages Grameen Bank women to be able to use the knowledge for the improvement of personal life and citizenry development in their communities. This paper discovers GB non-declared adult learning and its implication to borrowers' social life.

\subsection{Limitations of the study}

The study measures GB women borrowers' family space and public space development through knowing and following the Sixteen Decisions, but do not measure their economic development and micro-enterprise development that is also significant. Without verification, the researcher recorded participants' self-reported statements during the interview. The paper does not have primary survey data on the impact of GB borrowers in their life. The study only reviews GB sixteen decisions adult learning campaigns and adult women center meetings outcomes.

\subsection{Validity}

This paper has intrinsic validity because it defines and reviews non-formal learning skills from adult educators and adult learners' perspectives and contexts. The paper has external validity too through careful review and analysis of GB adult learning strategies and implementations. The GB sixteen decisions adult 
education campaign lenses from Freirean literacy through empowering GB borrowers' by GB adult learning different techniques and events (seven days workshops, exchange visits and group training etc.).

\section{Suggestions and Conclusion}

\subsection{Suggestions}

The GB "Sixteen Decisions Awareness Creation Campaign" through workshops, mini group sessions, and training has been reduced since 1999. Restarting the "Sixteen Decisions Awareness Campaign" with a new approach is important. GB could focus on formalizing and streamlining its non-formal adult learning, which could give way to more sustained adult learning that more effectively responds to the needs of GB borrowers' context and to their family members and also other disadvantaged groups in Bangladesh. GB could provide adult training to its field staff following non-formal learning principles, which could be use more effective ways for adult learning. The GB efforts to adult learning could be looked at by other MFIs/ NGOs and receive lesions from it and apply in their programs whatever applicable in Bangladesh.

The author agrees with Education Watch (2005) flexible way with contextual mass adult literacy education program through involvement of adult learners in development activities, including income generations activities, numeracy and financial literacy, public health education, mother and child health education and other specific skills learning programs are important(Becker, 1993; Bouchard, 2006); Ontario Public Health Association \& Frontier College, 1989). GB could develop non-formal learning reading materials and written materials with attractive audio video films, cartons, pictures (visual arts) and technical support tailor to the local conditions and with local cultural expressions could make available to GB borrowers' families and other adult learners in Bangladesh.

\subsection{Conclusion}

As GB borrowers graduate and achieve some of their basic socio-economic and civic issues, Grameen Bank organizes workshops and seminars against male chauvinism and gender discrimination in the family and in the community. Also, it is very important that GB advocate for law enforcement for dowry violence, teen age marriage at both the macro level and grass roots level. The GB credit and non-credit programs can have a more positive impact on Bangladesh, if the Grameen Bank adult learning facilitates and works more on following two-way dialogue style communication adult learning strategies. These actions would develop women's critical thinking development and leadership development so that they may cope with the existing social norms and values in their communities.

\section{References:}

Abdullah, T. A., \& Zeidenstein S. A. (1982). Village women of Bangladesh: Prospects for change. Oxford: Pergamon Press.

Action Aid. (2000). REFLECT Condition Unit Annual Report 2000. London: Action Aid.

Ahmed M. (2002b). Lifelong learning and the learning society. In M. Singh (Ed.), Institutionalizing lifelong learning. Hamburg: UNESCO Institute for Education.

Ahmed, M. (1999). Literacy and national education: Overlap and divergence. In D. Wagner et. al (Eds.), Literacy: An international handbook, Colorado: Westview Press.

Ahmed, M. (2002a). Confusion about Literacy: Can it Help Fight poverty? Dhaka; The Daily Star, 28, April 2002.

Ahmed, S., \& Hakim, M. A. (2004). Attacking poverty with micro credit. Dhaka: The University Press Ltd. Bangladesh Bureau of Statistics. (2001). Population Census 2001. Preliminary Report, Dhaka: Bangladesh Bureau of Statistics.

Becker, G. (1993). Human capital. Chicago: The University of Chicago press. 
Grameen Bank women borrowers' non-formal adult learning transformation in Bangladesh

http://dx.doi.org/10.7208/chicago/9780226041223.001.0001

Bhola, H. S. (1984). Campaigning for literacy. Paris: UNESCO.

Bouchard, P. (2006). Human capital and the knowledge economy. In T. Fenwick, T. Nesbit, \& B. Spencer (Eds.) Contexts of adult education: Canadian perspectives (pp. 164-172). Toronto: Thompson Educational Publishing, Inc.

Brigham, S. M., \& Gouthro, P. A. (2006). Cross-cultural Teaching and Research in Adult Education. In T. Fenwick, T. Nesbit, \& B. Spencer (Eds.) Contexts of adult education: Canadian perspectives (pp. 81-91). Toronto: Thompson Educational Publishing, Inc.

Burton, W., \& Point, G. (2006). Histories of aboriginal adult education in Canada. In T. Fenwick, T. Nesbit, \& B. Spencer (Eds.) Contexts of adult education: Canadian perspectives (pp. 36-48). Toronto: Thompson Educational Publishing, Inc.

Chowdhury, A., R., Nath, S. R., \& Chowdhury, R. K. (2002). Enrolment at primary level, gender differences disappears in Bangladesh. International Journal of Educational Development, 22, 191-203. http://dx.doi.org/10.1016/S0738-0593(01)00027-X

Clover, D. E. (2003). Environmental adult education: Critique and creativity in a globalizing world. In H. L. Hill \& D. E. Clover (Eds.), Environmental adult education: Ecological learning, theory, and practice for socio-environmental change (pp. 5-16). San Francisco: Jossey-Bass.

Coady, M. (1939). Masters of their own destiny. New York: Harper and Row.

Collins, M. (2006). The critical legacy: Adult education against the claims of capital. In T. Fenwick, T. Nesbit, \& B. Spencer (Eds.) Contexts of adult education: Canadian perspectives (pp. 118-127). Toronto: Thompson Educational Publishing, Inc.

Darlene, E. C. (2006). Environmental Adult Education in Canada. In Contexts of adult education: Canadian Perspectives. Eds. Tara Fenwick, Tom Nesbit, Bruce Spencer. (2006). Toronto: Thompson Educational Publishing, Inc.

Deneer J. T. (1981). The Nicaraguan literacy crusade. Journal of Reading, 25, 118-125.

Draper, J. (1998). Introduction to the Canadian chronology. Canadian Journal for Studies in Adult Education/RCEEA, 12(2), 33-43.

Education Watch. (2002). Literacy in Bangladesh-need for a new vision. Dhaka: Campaign for Popular Education.

Education Watch. (2005). Literacy in Bangladesh-need for a new vision. Dhaka: Campaign for Popular Education.

English, L. M. (2006). Post-foundationalism. In T. Fenwick, T. Nesbit, \& B. Spencer (Eds.) Contexts of adult education: Canadian perspectives (pp. 105-117). Toronto: Thompson Educational Publishing, Inc.

English, L. M., \& Gillen, M. A. (2000). A postmodern approach to adult religious education. In A. I. Wilson \& E. Hayes (Eds.), Handbook of adult and continuing education (pp. 523-538). San Francisco: Jessey-Bass.

Fenwick, T. J. (2006). Work, learning and adult education in Canada. In T. Fenwick, T. Nesbit, \& B. Spencer (Eds.) Contexts of adult education: Canadian perspectives (pp. 187-197). Toronto: Thompson Educational Publishing, Inc.

Foucault, M. (1984). What is enlightenment. In P. Rabinow (Ed.), The Foucault reader (C. Porter, Trans.; pp. 32-50). New York: Pantheon Books.

Freire, P. (1970). Pedagogy of the oppressed. New York: Seabury Press.

Freire, P. (1972). Pedagogy of oppressed. Harmondsworth: Penguin.

Freire, P. (1973). Education for critical consciousness. London: Sheed and Ward.

Government of Bangladesh. (1990). The Education (compulsory) Act, 1990. Bangladesh Gazette, 5(13). Dhaka: Government of Bangladesh 9 in Bangla.

Grace, A. P. (2006). Critical Adult Education: Engaging the social in theory and practice. In T. Fenwick, T.

Nesbit, \& B. Spencer (Eds.) Contexts of adult education: Canadian perspectives (pp. 128-139). Toronto: Thompson Educational Publishing, Inc.

Haq, M. \& Haq, K. (1998). Human development in South Asia 1998. Karachi: Oxford University Press.

Henry, S. (2006). How MFI's and their clients can have a positive impact on the environment. Good practices in 
business development services: how do we enhance entrepreneurial skills in MFIs clients? Paper presented at the Micro Credit Summit Halifax held in November 2006. Toronto: Alterna Savings.

Henson, G. (1946). Provincial support of adult education in Nova Scotia: A report by Guy Henson. Halifax, NS: King's Printer.

Hussain, S. (2000). Total Literacy Movement (TLM): Learning through Experience. Proshikhyan, 8(2), 1-10.

Illeris, K. (2002). The three dimensions of learning: Contemporary learning theory in the tension field between the cognitive, the emotional, and the social. Frederiksberg, Denmark: Roskilde University Press.

Jahan, R. (1995). The elusive agenda: Mainstreaming women in development. Dhaka: The University Press Ltd.

Jennings, J. (1990). Adult literacy: Master or servant? Dhaka: University Press Limited.

Joan, H et al. (2006). How MFI's and their clients can have a positive impact on the environment. Paper presented in the Micro-credit Summit Campaign. Halifax

Jung, C. (1954). The development of personality (R. F. C. Hull, Trans.), Princeton, NJ: Princeton University Press.

Korten, D. (2006). The great turning from empire to earth community. Connecticut: Kumarian Press Inc.

Lange, E., A. (2006). Challenging social philosophobia. In T. Fenwick, T. Nesbit, \& B. Spencer (Eds.) Contexts of adult education: Canadian perspectives (pp. 92-104). Toronto: Thompson Educational Publishing, Inc.

Mahmud, S. (2004). Microcredit and women's empowerment in Bangladesh. In S. Ahmed \& S. Hakim (Eds.), Attacking poverty with microcredit (pp. 148-153). Dhaka: The University Press Limited.

NABBEIS. (2000). Bangladesh Education Statistics (at a glance) 2000. Dhaka: Bangladesh Bureau of Educational Information and Statistics (BANBEIS).

Nath, S. R. (2002). Education watch 2002; Literacy situation in Bangladesh; Instruction Mmanual for interviewers (in Bangla). Dhaka: BRAC Research and valuation Division.

Nath, S. R., \& Chouwdhury, A. R (Eds.) 2001). A question of quality-state of primary education in Bangladesh. Achievement of competencies (Vol 11). Dhaka: Campaign for Popular Education and University Press Limited.

Nesbit, T. (2006). Introduction. In T. Fenwick, T. Nesbit, \& B. Spencer (Eds.) Contexts of adult education: Canadian perspectives (pp. 13-22). Toronto: Thompson Educational Publishing, Inc.

OECD. (1996). Lifelong learning for all. Meeting of the education committee at ministerial level, 16-17 January 1996. Paris: Organization for Economic Cooperation and Development.

Ontario Public Health Association \& Frontier College. (1989). Literacy and Health Project, Phase one: Making the world healthier and safer for people who can't read. Toronto: Ontario Public Health Association, Frontier College.

Poonwassie, D. ( 2001). Parental involvements as adult education: A microstrategy for change. In K. Binda \& S. Calliou (Eds.) Aboriginal education in Canada: A study in decolonization (pp. 155-165). Mississauga, ON. Canadian Educators' Press.

Rathgeber, E. (1990). WID, WAD, GAD: Trends in research and practice. Journal of Developing Areas, 24(4), 489-502.

Rouf, K. A. (2011). Grameen Bank women borrowers familial and community relationships development in patriarchal Bangladesh. International Journal of Research Studies in Psychology, 1(1), 17-26.

Rubenson, K., \& Walker, J. (2006). The political economy of Adult Learning in Canada. In T. Fenwick, T. Nesbit, \& B. Spencer (Eds.) Contexts of adult education: Canadian perspectives (pp. 173-186). Toronto: Thompson Educational Publishing, Inc.

Sawchuk, P. (2006). Frameworks for synthesis of the field of adult learning theory. In T. Fenwick, T. Nesbit, \& B. Spencer (Eds.) Contexts of adult education: Canadian perspectives (pp. 140-152). Toronto: Thompson Educational Publishing, Inc.

Scott, S. M., Spencer, B., \& Thomas A. M. (Eds.). (1998). Learning for life: Canadian readings in adult education. Toronto, ON: Thompson Educational.

Selman, G. (1998). The foundation of adult education in Canada ( $2^{\text {nd }}$ ed.). Toronto, ON: Thompson Educational Publishing, Inc. 
Selman, G., \& Dampier, P. (1991). The foundations of adult education in Canada. Toronto, ON: Thompson Educational Publishing, Inc.

Sen, A. (1995). India: Economic development and social opportunity. Delhi, Oxford University Press.

The Daily Star. (2002). Special supplement education for all week. The Daily Star, Dhaka, April 22, 2002.

Todd, H. (1996). Women at the centre: Grameen bank borrowers after one decades. Dhaka: The University Press limited.

Tomkins, J. (1921). Knowledge for the people. Antigonish, NS: St. Francis Xavier University.

UNDP. (1999). Human development report. New York: Oxford University Press.

UNESCO. (1997). Final report of fifth international conference on adult education. Paris: UNESCO.

UNESCO. (2000). The Dakar framework of action. Paris UNESCO.

UNICEF. (1992). Assessment of basic competencies of children in Bangladesh: A status report. Dhaka: UNICEF.

WCEFA. (1990). World conference on education for all: Meeting learning needs. Jomtien, Paris: UNESCO.

Welton, M. (2003). De-coding Coady: Masters of their own destiny under critical scrutiny. Studies in Continuing Education, 25(1), 75-93. http://dx.doi.org/10.1080/01580370309283

Welton, M. (Ed.) (2003). In defence of the life world: Critical perspectives on adult learning. Albany: State University of New York.

Welton, M. R. (1995). The critical turn in adult education theory. In M. R. Welton (Ed.), Defence of the life world: Critical perspectives on adult learning (pp. 11-38). New York: State University of New York.

Yunus, M. (2008). Creating a world without poverty. Dhaka: Subarna Publications Ltd. 
Rouf, K. A. 